\title{
Meta Analisis Pengaruh Model Discovery Learning terhadap Hasil Belajar Siswa Pada Mata Pelajaran PAI
}

\author{
Syifa Aghnia Zaenal", Erhamwilda \\ Islam Bandung, Indonesia. \\ *syifaaghnia13@gmail.com, erhamhoernis@gmail.com
}

Prodi Pendidikan Agama Islam, Fakultas Tarbiyah dan Keguruan, Universitas

\begin{abstract}
The problem in this study is the use of meta analysis to determine the effectiveness of the influence of discovery learning model on student learning outcomes based on elementary-high school/vocational education level in PAI subjects. Then next to find recommendations that can be given after the meta analysis. Researchers took fifteen published research articles from forty-seven articles to be calculated using a metaanalysis process. The design of this study uses meta design analysis of pre post contrats. Data collection techniques used by conducting documentation studies or library studies. As a result, from this study, it was obtained that the effectiveness of the discovery learning model on students' learning outcomes in PAI subjects is seen based on the level of education, high school level has a higher effectiveness among elementary and junior high school level. Based on the results of the calculations conducted, in fifteen research articles obtained magnitude effect of 11.60 with an average correlation of 0.31 is in the category of weak effects. However, after testing analysis using JASP software version 0.14.1.0 obtained a p-value (two-tailed) that is less than $\alpha(0.05)$. Since $p-$ value $<\alpha(0.05)$, the $H$ is rejected, in which case the true effect size is not equal to zero. So based on random effect model, there is a difference in effectiveness between discovery learning model in PAI subjects based on education level compared to conventional model reviewed from student learning results based on studies conducted in 2010-2020.
\end{abstract}

Keywords: Meta Analysis, Discovery Learning, Learning Outcomes, PAI Subjects

\begin{abstract}
Abstrak. Permasalahan pada penelitian ini yaitu, penggunaan meta analisis untuk mengetahui keefektivan pengaruh model discovery learning terhadap hasil belajar siswa berdasarkan jenjang pendidikan SDSMA/SMK pada mata pelajaran PAI. Kemudian selanjutnya untuk menemukan rekomendasi yang dapat diberikan setelah dilakukannya meta analisis. Peneliti mengambil lima belas artikel penelitian terpublikasi dari empat puluh tujuh artikel untuk dilakukan perhitungan dengan menggunakan proses meta analisis. Desain penelitian ini menggunakan desain meta analisis pre post contrats. Teknik pengumpulan data yang digunakan dengan melakukan studi dokumentasi atau studi pustaka. Hasilnya, dari penelitian ini diperoleh bahwa yang memiliki keefektifan pengaruh model discovery learning terhadap hasil belajar siswa pada mata pelajaran PAI dilihat berdasarkan jenjang pendidikan, jenjang SMA memiliki nilai yang lebih tinggi keefektivannya di antara tingkat SD dan SMP. Berdasarkan hasil perhitungan yang dilakukan, pada lima belas artikel penelitian diperoleh magnitude effect sebesar 11.60 dengan rata-rata korelasi 0.31 berada dalam kategori efek lemah. Namun demikian setelah dilakukan analisis uji menggunakan software JASP versi 0.14.1.0 memperoleh nilai p-value (two-tailed) yang kurang dari $\alpha(0.05)$. Karena $p$-value $<\alpha(0.05)$, maka Ho ditolak, dalam hal ini true effect size tidak sama dengan nol. Sehingga berdasarkan random effect model, terdapat perbedaan keefektivan antara model discovery learning pada mata pelajaran PAI berdasarkan jenjang pendidikan dibandingkan dengan model konvensional ditinjau dari hasil belajar siswa berdasarkan studi yang dilakukan pada tahun 2010-2020.
\end{abstract}

Kata Kunci: Meta Analisis, Discovery Learning, Hasil Belajar, Mata Pelajaran PAI 


\section{A. Pendahuluan}

Salah satu faktor penting untuk mencapai tujuan pembelajaran adalah dengan pemilihan penggunaan model pembelajaran. Pemilihan model pembelajaran yang tepat dapat membantu guru untuk menciptakan tujuan belajar secara optimal dan siswa memperoleh hasil belajar yang lebih baik. Salah satu model pembelajaran yang akan diuraikan dalam penelitian ini adalah model pembelajaran discovery learning.

Berdasarkan studi pustaka yang telah dilakukan, yaitu dengan mengamati berkas data penelitian terdahulu, pengaruh model discovery learning pada mata pelajaran PAI ini telah banyak dilakukan penelitiannya. Peneliti menemukan empat puluh delapan artikel penelitian yang dipublikasikan dalam rentang waktu 2010-2020. Kemudian berdasarkan hasil penelitian tersebut, model pembelajaran discovery learning ini cukup berpengaruh untuk meningkatkan hasil belajar siswa.

Karena banyaknya data penelitian terdahulu dalam bidang pendidikan mengenai model discovery learning pada mata pelajaran PAI, peneliti ingin melakukan analisis untuk menguji kembali keefektifan hasil penelitiannya. Oleh karena itu, untuk memenuhi pemecahan persoalan tersebut, peneliti menggunakan meta analisis sebagai sebuah alat untuk mengolah datanya. Meta analisis dapat digunakan untuk meringkas, merangkum dan memperoleh intisari hasil temuan dari sejumlah penelitian dengan cara mencari nilai besar pengaruh dari setiap studi yang dihasilkan. Data yang telah diperoleh, Selanjutnya digunakan sebagai acuan dasar untuk mendukung atau menolak hipotesis pada penelitian meta analisis. Selain itu, meta analisis ini berguna untuk menjadi penguat hasil dari penelitian sebelumnya.

Berdasarkan permasalahan yang telah diuraikan, maka perumusan masalah dalam penelitian ini sebagai berikut: "Apakah terdapat pengaruh penggunaan model discovery learning terhadap hasil belajar siswa pada mata pelajaran PAI berdasarkan jenjang pendidikan?". Selanjutnya, tujuan dalam penelitian ini diuraikan dalam pokok-pokok sebagai berikut:

1. Untuk mengetahui besar pengaruh model discovery learning terhadap hasil belajar siswa pada mata pelajaran PAI berdasarkan jenjang pendidikan SD.

2. Untuk mengetahui besar pengaruh model discovery learning terhadap hasil belajar siswa pada mata pelajaran PAI berdasarkan jenjang pendidikan SMP

3. Untuk mengetahui besar pengaruh model discovery learning terhadap hasil belajar siswa pada mata pelajaran PAI berdasarkan jenjang pendidikan SMA/SMK.

4. Untuk menemukan rekomendasi yang dapat diberikan terkait dengan pengaruh model discovery learning terhadap hasil belajar siswa pada mata pelajaran PAI berdasarkan jenjang pendidikan dan wilayah setelah dilakukan meta analisis.

\section{B. Metodologi}

Metode penelitian yang digunakan adalah kuantitatif dengan menggunakan meta analisis sebagai alat untuk mengolah datanya. Karena meta analisis merupakan penelitian yang dilakukan dengan menganalisis data sekunder terhadap permasalahan sejenis untuk memperoleh hasil yang lebih akurat, sehingga dapat memberikan rekomendasi setelah dilakukannya meta analisis. Sementara jenis penelitiannya adalah statistik deskriptif, dengan desain penelitian meta analisis pre post contrats. Variabel dalam penelitiannya adalah variabel bebas yaitu model discovery learning dan variabel terikat hasil belajar siswa pada mata pelajaran PAI.

Kemudian dalam penelitian ini menggunakan data sekunder. Dimana populasi nya adalah artikel hasil penelitian dalam lingkup pendidikan yang telah dipublikasikan secara nasional berjumlah empat puluh tujuh artikel penelitian yang memiliki satu topik atau tema yang sama mengenai pengaruh model pembelajaran discovery learning pada mata pelajaran PAI. Selanjutnya sampel penelitiannya adalah artikel yang telah dipublikasikan secara nasional pada rentang waktu 2010-2020 yang berjumlah lima belas artikel penelitian mengenai pengaruh model pembelajaran discovey learning terhadap hasil belajar siswa pada mata pelajaran PAI dengan memperhatikan kriteria inklusi dan ekslusi yang telah ditetapkan. Berikut adalah daftar artikel penelitiannya: 
1. Jurnal, dengan judul "Pengaruh Pendekatan Saintifik dengan Model Discovery Learning Terhadap Hasil Belajar Siswa pada Pelajaran PAI Kelas VII SMP A Wahid Hasyim Ngoro" (Siti Umdlotul, dkk : 2020).

2. Skripsi, dengan judul "Pengaruh Efektivitas Pembelajaran Pendidikan Agama Islam

3. Skripsi, dengan judul "Pengaruh Penggunaan Model Discovery Learning Untuk Meningkatkan Akhlakul Karimah Pada Pelajaran Pendidikan Agama Islam Siswa Kelas X SMA Negeri 10 Bandar Lampung" (Tyas Rohmansyah, 2019).

4. Skripsi, dengan judul "Pengaruh Penerapan Model Pembelajaran Discovery Learning Oleh Guru Terhadap Hasil Belajar Siswa Pada Mata Pelajaran Pendidikan Agama Islam di Sekolah Menengah Pertama Se-Kecamatan Rumbai Pesisir" (Shilfia Alfitry, 2020).

5. Skripsi, dengan judul "Pengaruh Penerapan Model Pembelajaran Discovery Learning Pada Pelajaran PAI Terhadap Hasil Belajar Siswa di SMP Negeri 2 Kota Jambi”" (Lia Amaliah, 2019).

6. Skripsi, dengan judul "Pengaruh Penerapan Model Pembelajaran Discovery Learning Terhadap Hasil Belajar Siswa dalam Mata Pelajaran Pendidikan Agama Islam (Studi di SMK Negeri 1 Kragilan)" (Subandi, 2016).

7. Skripsi, dengan judul "Pengaruh Efektivitas Model Pembelajaran Discovery Learning Terhadap Hasil Belajar Mata Pelajaran PAI Pada Siswa Kelas VIII Semester 1 SMP NU 01 Muallimin Weleri Tahun Pelajaran 2010-2011" (Faridah, n.d.).

8. Jurnal, dengan judul "Pengaruh Model Pembelajaran Discovery Learning Untuk Meningkatkan Hasil Belajar Pendidikan Agama dan Budi Pekerti Pada Siswa Kelas XIPA Di SMAN 5 Bekasi Pada Tahun 2017/2018" (Supriatna, 2018).

9. Skripsi, dengan judul "Pengaruh Implementasi Model Discovery Learning Terhadap Hasil Belajar PAI Siswa Kelas X IIS-1 di SMA Al-Falah Surabaya" (Nafilatur Rahmah Qadarisman, n.d.).

10. Jurnal, dengan judul "Pengaruh Model Pembelajaran Discovery Learning Terhadap Hasil Belajar Siswa Pada Mata Pelajaran PAI Kelas VII di SMP Patra Mandiri 01 Palembang" (Ismail Sukardi, Indah Wigati, 2015). (PAI) Dengan Model Discovery Learning dalam Meningkatkan Hasil Belajar Siswa di SMP Negeri I Lawang Wetan" (Tenti Anggreasi, 2017).

11. Skripsi, dengan judul "Pengaruh Penggunaan Model Pembelajaran Discovery Learning Terhadap Hasil Belajar Siswa Pada Mata Pelajaran PAI (Kompetensi Dasar Mengenal Tata Cara Bersuci ) di Sekolah Dasar Islam Terpadu (SD IT) Al Hikmah Kota Cirebon" (Kholid Nugraha, n.d.).

12. Skripsi, dengan judul "Pengaruh Model Pembelajaran Discovery Learning Terhadap Hasil Belajar Siswa Pada Mata Pelajaran PAI Kelas XII Multimedia di Sekolah Menengah Kejuruan Negeri 1 Ponorogo Tahun Ajaran 2019/2020" (Nikamatul Rohmawati, 2020).

13. Jurnal, dengan judul "Pengaruh Penerapan Model Pembelajaran Discovery Learning dalam Upaya Peningkatan Hasil Belajar Siswa pada Pembelajaran PAI dan Budi Pekerti Pokok Bahasan Semua Bersih Hidup Jadi Nyaman di Kelas VII-1 SMP Negeri 1 Batangtoru Tahun Pelajaran 2018/2019" (Yasrida Yanti Sihombing, 2018).

14. Skripsi, dengan judul "Pengaruh Model Discovery Learning Terhadap Hasil Belajar PAI Peserta Didik Kelas IV SD Islam Al-Azhar Tulungagung” (Nafidatun Nadhiroh, 2017).

15. Jurnal, dengan judul "Pengaruh Efektivitas Model Discovery Learning Terhadap Hasil Belajar PAI Siswa Kelas V" (Anisah Dwi Jayanti, Ummu Khairiyah, 2020).

Teknik pengumpulan data dalam penelitian ini adalah dengan melakukan studi dokumentasi atau studi pustaka pada jurnal dan skripsi. sementara instrumen penelitian yang digunakan pada penelitian ini adalah dengan memakai lembar pemberian kode (coding data). Adapun variabel yang digunakan dalam coding data untuk menjaring informasi mengenai effect size penelitian antara lain, nama peneliti, tahun penelitian, subjek penelitian, variabel bebas dan variabel terikat, desain penelitian, ukuran sampel, dan analisis data. Kemudian untuk teknik analisis data yang digunakan adalah dengan menghitung effect size, variansi effect size dan standard error dari effect size. Menghitung summary untuk effect size, variansi effect, standard 
error effect. Menghitung interval kepercayaan. Melakukan uji hipotesis dengan menghitung nilai $\mathrm{Z}$ dan $p$-value, serta terakhir yaitu membuat interpretasi dan kesimpulan hasil analisis (Retnawati, 2018:72).

\section{Pembahasan dan Diskusi}

Model discovery learning pada mata pelajaran PAI ini berupaya untuk menanamkan dasar-dasar berpikir ilmiah pada diri siswa. Sehingga dalam proses pembelajaran, siswa lebih banyak belajar sendiri untuk mengembangkan kreativitas dalam memecahkan masalah. Sehingga fungsi pendidikan akan sejalan dengan apa yang diharapkan. Yaitu mengoptimalkan potensi akal untuk berpikir. Hal ini sesuai dengan firman Allah dalam Q.S Ali Imran ayat 190 yaitu :

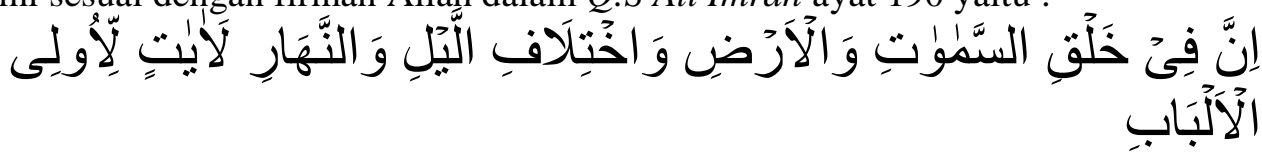

Artinya: "Sesungguhnya dalam penciptaan langit dan bumi, dan pergantian malam dan siang terdapat tanda-tanda (kebesaran Allah) bagi orang yang berakal" (Departemen Agama RI, 1984: 109).

Ayat di atas menerangkan bahwa pendidikan harus mempertimbakan manusia yang merupakan sasaran dari pelaku pendidikan. Karena manusia merupakan makhluk yang dianugerahi akal oleh Allah dengan berbagai fungsi variatif. Pendidikan yang baik merupakan pendidikan yang dapat mempertimbangkan potensi akal. Dengan mempertimbangkan potensi akal, pendidikan mampu untuk membina, mengarahkan dan mengembangkan kemampuan dalam memecahkan masalah yang ada. Di mana hal tersebut memuat berbagai konsep bidang ilmu pengetahuan dan teknologi, dengan kemampuan pemahaman yang baik dan benar (Abuddin, 2012: 129).

Sehingga hal ini sangat berkaitan dengan hasil perhitungan Bagan 1. Effect Size Berdasarkan Jenjang Pendidikan yang ada di bawah ini:

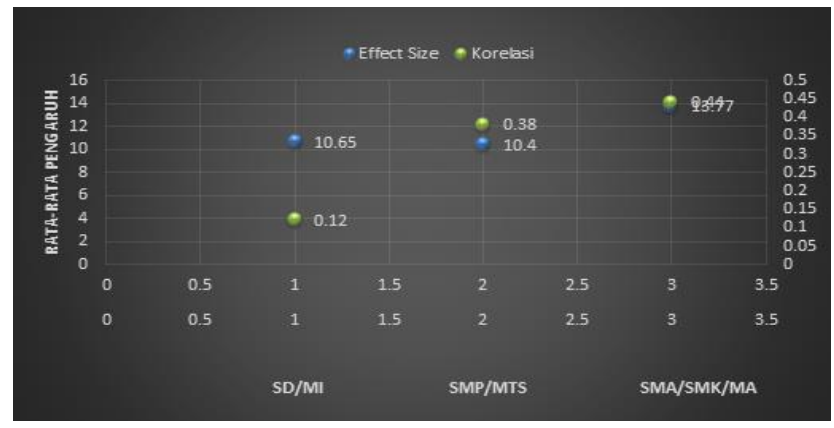

Gambar 1.

Berdasarkan Gambar 1. di atas, model discovery learning ini dapat memberikan magnitude effect pada tingkat SD sebesar 10.65 dengan korelasi 0.12 berada dalam kategori efek sangat lemah. Sedangkan tingkat SMP memberikan magnitude effect 10.40 dengan korelasi 0.38 berada dalam kategori efek lemah. Lalu terakhir pada tingkat SMA/SMK memberikan magnitude effect 13.77 dengan korelasi 0.44 berada dalam kategori efek sedang. Sehingga, pada bagan tersebut jenjang SMA/SMK merupakan jenjang pendidikan yang memberikan effect size paling besar dari nilai korelasi yang diperoleh. Karena nilai korelasi yang dihasilkan lebih tinggi dibandingkan jenjang SD dan SMP, maka dari data tersebut, menyatakan bahwa jenjang pendidikan SMA/SMK paling efektif digunakan untuk model discovery learning terhadap hasil belajar siswa pada mata pelajaran PAI berdasarkan jenjang pendidikan.

Hal ini dapat terjadi selain jenjang pendidikan yang lebih tinggi, disebabkan juga dengan perbedaan usia yang sudah mendekati efisiensi intelektual yang maksimal. Selain itu, tingkat perkembangan siswa pada jenjang pendidikan SMA/SMK berada pada tingkatan yang lebih besar dibandingkan dengan jenjang pendidikan SD atau SMP. Fungsi intelektual atau 
kemampuan akal siswa dalam dunia pendidikan dikenal dengan istilah kognitif, yang berarti mengetahui. Menurut Piaget, dalam aspek kognitif pada masa remaja jenjang SMA/SMK ini sudah mampu untuk memahami konsep abstrak dan hipotesis dalam batas tertentu atau berpikir operasional formal (Suparno, 2001: 88). Di mana mereka telah mampu memikirkan semua kemungkinan secara sistematik untuk memecahkan masalah. Mereka juga memiliki kemampuan berpikir alternatif, sehingga kemungkinan untuk menyelesaikan masalah yang mereka hadapi lebih beragam.

Sementara itu untuk jenjang pendidikan SMP, jika mengacu pada teori yang dikemukakan oleh Erhamwilda (2016: 144-145) menyatakan bahwa siswa SMP berada dalam tingkatan discovery di mana guru memberikan penjelasan secara rinci lalu siswa mengemukakan contoh-contoh dari konsep yang telah dijelaskan oleh guru. Kemudian selanjutnya pada jenjang pendidikan SD berada pada tingkatan guru sudah menjelaskan konsep dan contohnya secara rinci. Lalu siswa hanya perlu mencari contoh lainnya.

Pada aspek koginitif jenjang pendidikan SD mengacu pada teori kognitif Piaget. Di mana pemikiran pada anak usia sekolah dasar mulai pada tahap pemikiran konkret-operasional (concrete operational thought). Yaitu sebuah tahap di mana berfokus pada objek-objek nyata atau pada berbagai kejadian yang pernah dialami pada aktivitas mentalnya.

Menurut Piaget, anak yang berada pada masa konkret operasional ini sudah dapat menyadari konservasi. Di mana hal ini merupakan kemampuan anak untuk berhubungan dengan sejumlah aspek berbeda secara serempak (Johnson \& Medinnus, 1974). Namun keterbatasan yang terjadi pada kemampuan anak berpikir konkret adalah egosentrisme. Yakni anak belum mampu membedakan antara perbuatan dan objek yang dialami secara langsung di mana hanya ada dalam pikirannya. Sehingga hal inilah yang menyebabkan perolehan hasil magnitude effect pada jenjang pendidikan SD berada pada kategori efek sangat lemah dengan nilai korelasi sebesar 0.12 . Namun demikian, model discovery ini dapat diterapkan sejak dini agar dapat membantu siswa untuk menggunakan ingatannya karena melibatkan pengalaman sendiri kemudian nantinya dapat mentransfer pada situasi belajar yang baru.

Selain itu menurut Erhamwilda (2016: 144) menyatakan bahwa kemampuan siswa dalam memecahkan masalah harus dilatih sejak dini sesuai kapasitasnya. Oleh karena itu menurut Roestiyah (1998: 76) keunggulan dari model ini dapat membantu siswa untuk dapat mengembangkan bakat atau kecakapan individu, bersikap objektif jujur dan terbuka dari sejak dini. Namun disamping memiliki keunggulan, model ini memiliki kelemahan. Itulah yang menjadi alasan mengapa berdasarkan hasil perhitungan yang dihasilkan pada Bagan 1 pengaruh model discovery learning terhadap hasil belajar pada jenjang pendidikan SD berada dalam kategori efek sangat lemah. Hal tersebut menurut menurut Roestiyah (1998: 77) dapat terjadi karena tidak semua siswa dapat mengikuti proses pembelajaran dengan model seperti ini, sebab terbiasa belajar dengan diberikan materi oleh guru. Lalu membutuhkan waktu yang relatif lama dalam pengimplementasiannya. Sehingga guru sulit menyesuaikannya dengan waktu yang telah ditetapkan.

Kemudian berdasarkan hasil perhitungan yang diperoleh pada Bagan 1 menunjukkan bahwa untuk jenjang SMP ini berada pada perolehan magnitude effect dengan kategori efek lemah berada pada nilai korelasi 0.38. Hal ini dapat terjadi karena berdasarkan aspek kognitif menurut Piaget (1970), periode SMP ini disebut dengan period of formal operation. Pada usia ini berkembang kemampuan berpikir secara simbolis dan mampu memahami sesuatu secara bermakna (mean ingfully) tanpa membutuhkan objek yang konkret, bahkan objek yang visual. Karena siswa telah mampu memahami hal-hal yang bersifat imajinatif.

Implikasinya dalam pembelajaran PAI yaitu, pembelajaran akan bermakna apabila input (materi pelajaran) sejalan dengan minat dan bakat siswa. Pembelajaran PAI akan berhasil apabila penyusun silabus dan guru mampu menyesuaikan tingkat kesulitan dan variasi input dengan harapan serta karakteristik siswa sehingga motivasi belajar mereka berada pada tingkat maksimal. Oleh karena itu pemilihan model belajar yang tepat akan sangat berpengaruh pada hasil yang diperoleh. Dalam hal ini, mengenai pengaruh penggunaan model discovery learning. Walaupun hasil yang diperoleh belum berada pada kategori efek baik karena perkembangan kemampuan berpikir yang belum maksimal, namun setidaknya penggunaan model ini dapat 
berpengaruh pada hasil belajar siswa.

Sehingga, berdasarkan apa yang telah diuraiakan di atas model discovery learning ini dapat memberikan pengaruh positif bagi siswa yang diberikan treatment model ini. Karena dari beberapa hasil penelitian yang ada dan dari hasil perhitungan effect size yang telah dilakukan model ini dapat memberikan pengaruh terhadap hasil belajar siswa berdasarkan jenjang pendidikan. Yaitu jenjang SD, SMP dan SMA/SMK walaupun menghasilkan kategori efek yang berbeda-beda. Selain itu hal ini diperkuat dengan uji hipotesis yang telah peneliti lakukan yaitu dapat dilihat pada Tabel 1. p-value (two tailed test) berikut ini:

Tabel 1. two tailed test

\begin{tabular}{|l|c|c|c|}
\hline Kriteria & Nilai Z & $p$-value (two tailed test) & Korelasi (r) \\
\hline Jenjang Pendidikan \\
\hline SD & 6.492 & 0.0001 & 0.12 \\
\hline SMP & 10.101 & 0.0000 & 0.38 \\
\hline SMA/SMK & 2.48 & 0.0132 & 0.44 \\
\hline
\end{tabular}

Berdasarkan Tabel 1 di atas menunjukkan nilai p-value yang kurang dari $\alpha(0.05)$. Karena $p$-value < $\alpha(0.05)$, maka $\mathrm{H}_{0}$ ditolak, dalam hal ini true effect size tidak sama dengan nol. Sehingga berdasarkan random effect model, terdapat perbedaan keefektifan antara model discovery learning terhadap hasil belajar siswa dengan model konvensional berdasarkan jenjang pendidikan SD, SMP dan SMA/SMK.

Lalu, berdasarkan penelitian yang telah dilakukan rekomendasi yang dapat diberikan melalui meta analisis model discovery learning terhadap hasil belajar siswa pada mata pelajaran PAI berdasarkan jenjang pendidikan ini adalah karena jenjang SMA/SMK memiliki magnitude effect yang lebih tinggi dibandingkan dengan jenjang pendidikan lainnya, maka rekomendasi yang dapat peneliti berikan yaitu, untuk jenjang SD sebaiknya penerapan model discovery learning ini diberikan tidak dimulai dari anak kelas 1-3. Karena walaupun sudah masuk tahap operasional konkret, namun kemampuannya masih sangat terbatas sekali. Menurut Taksonomi Bloom pada fase ranah kognitif, anak pada usia ini baru berada pada fase C1 (mengingat), C2 (memahami) dan C3 (menerapkan). Sementara model discovery learning ini mengupayakan siswanya untuk mampu berpikir kritis atas ilmu yang akan dipelajari. Sementara anak yang berada pada kelas 1-3 ini, kemampuan berpikir kritis nya masih sangat terbatas. Sehingga penerapan model discovery learning pada jenjang SD ini sebaiknya mulai diterapkan dari mulai kelas 4 sampai kelas 6.

Karena pada usia ini anak memiliki daya analisis kritis yang semakin baik dari usia sebelumnya. Di mana anak sudah mampu untuk menelaah pemasalahan secara mendalam dengan berbagai dimensi. Kemampuan kognitif C3 (menerapkan) pada anak jenjang SD kelas 4-6 berada jauh lebih baik dibandingkan pada usia sebelumnya. Karena anak tidak hanya mampu untuk menghitung dan mengubah melainkan sudah mampu untuk membandingkan berbagai objek yang ada. Kemudian pada usia 9-10 tahun, anak sudah memiliki kemampuan kognitif ranah $\mathrm{C} 4$ (menganalisis) yaitu "kemampuan untuk menguraikan atau merinci suatu bahan menurut bagian-bagian yang lebih kecil dan mampu memahami hubungan antar faktor satu dengan faktor lainnya (Anwar, 2017: 194).

Kemudian untuk jenjang SMP dan SMA rekomendasi yang dapat peneliti berikan adalah guru harus mampu menguasai teknik pembelajaran discovery learning ini. Karena kunci keberhasilan belajar itu terdapat pada gurunya. Jika dilihat dari tingkat perkembangan, siswa SMP dan SMA ini sudah berada pada tahapan yang layak untuk diterapkan model pembelajaran discovery learning. Walaupun memang memiliki tingkat kemampuan berpikir kritis yang berbeda. Selain itu guru harus dapat membaca situasi dan kondisi kelas. Karena model ini sulit diterapkan pada kuantitas siswa yang banyak. Sebab model ini merupakan suatu model pembelajaran yang berpusat pada siswa, di mana guru harus tetap menjadi pembimbing disaat pembelajaran berlangsung, untuk tercapai nya hasil belajar yang diharapkan. 


\section{Kesimpulan}

Berdasarkan temuan dan analisis hasil penelitian yang telah dilakukan, maka dapat disimpulkan bahwa besar pengaruh model discovery learning terhadap hasil belajar pada mata pelajaran PAI berdasarkan jenjang pendidikan menunjukkan bahwa jenjang SMA/SMK berada pada magnitude effect dengan nilai paling tinggi dibandingkan dengan jenjang pendidikan SD dan SMP yaitu effect size sebesar 13.77 dan nilai korelasi 0.44 berada dalam kategori efek sedang. Hal ini sesuai dengan variansi yang dihasilkan untuk jenjang pendidikan SMA/SMK memiliki nilai yang lebih menonjol dibandingkan jenjang lainnya, yaitu sebesar 30.886. faktor yang menyebabkan jenjang pendidikan SMA/SMK lebih tinggi, karena tingkat perkembangan siswa setiap jenjang pendidikan sangat berpengaruh pada hasil belajar yang diperoleh. Jenjang pendidikan SMA/SMK memiliki kemampuan daya analisis kritis yang lebih baik dibandingkan jenjang pendidikan SD dan SMP. Berdasarkan uji hipotesis yang dilakukan menggunakan software JASP versi 0.14.1.0 setelah dilakukan perhitungan pada masing-masing jenjang pendidikan yaitu SD, SMP dan SMA/SMK, ketiganya memiliki nilai p-value (one-tailed dan two-tailed) yang kurang dari $\alpha(0.05)$. Karena $p$-value $<\alpha(0.05)$, maka $\mathrm{H}_{0}$ ditolak, dalam hal ini true effect size tidak sama dengan nol. Sehingga berdasarkan random effect model, terdapat perbedaan keefektifan antara model discovery learning terhadap hasil belajar siswa dengan model konvensional berdasarkan jenjang pendidikan SD, SMP dan SMA/SMK.

\section{Acknowledge}

Selama menyelesaikan penelitian ini ini penulis menerima banyak dukungan dan bantuan dari berbagai pihak, baik secara langsung maupun tidak langsung. Untuk itu penulis ucapkan terima kasih yang sebesar-besarnya kepada berbagai pihak yang turut membantu, khususnya kepada:

1. Enoh, Drs., M.Ag selaku Dekan Fakultas Tarbiyah dan Keguruan Universitas Islam Bandung.

2. Dr. Aep Saepudin, Drs., M.Ag selaku Ketua Prodi Pendidikan Agama Islam Fakultas Tarbiyah dan Keguruan Universitas Islam Bandung.

3. Dr. Hj. Erhamwilda, Dra., M.Pd. selaku dosen pembimbing I dan Khambali, S.Pd.I., M.Pd.I. selaku dosen pembimbing II yang telah sabar serta telah banyak meluangkan waktu dan pemikirannya untuk membimbing penulis dari awal proses pembuatan penelitian ini hingga akhir.

4. Dr. Nan Rahminawati, Drs., M.Pd. Dr. Asep Dudi Suhardini, M.Pd. H. U Saifuddin ASM, Drs., M. Ag. Khambali, S.Pd., M. Pd.I. selaku dosen penguji 1, dosen penguji 2, dosen penguji 3 dan dosen penguji 4.

5. Kepada para dosen, seluruh staf serta karyawan yang ada di Fakultas Tarbiyah dan Keguruan Universitas Islam Bandung yang telah membantu dan menudukung selama masa kuliah berlangsung.

6. Pa Hendra Laboratorium Statistik MIPA Universitas Islam Bandung yang telah mengarahkan dan membantu penulis untuk menyelesaikan penelitian ini

\section{Daftar Pustaka}

[1] Abuddin. (2012). Tafsir Ayat-ayat Pendidikan. Raja Grafindo Persada.

[2] Anisah Dwi Jayanti, Ummu Khairiyah, S. N. F. (2020). Pengaruh Efektivitas Model Discovery Learning Terhadap Hasil Belajar PAI Siswa Kelas V. Jurnal Keislaman, Vol 1(1).

[3] Anwar, C. (2017). Teori-teori Pendidikan Klasik Hingga Kontemporer. IRCiSoD.

[4] Departemen Agama RI. (1984). Al-Qur'an dan Terjemahnya. Proyek Pengadaan Kitab Suci al-Qur'an Dept. Agama RI.

[5] Erhamwilda. (2016). Psikologi Belajar Islami. PG PAUD Fakultas Tarbiyah dan Keguruan Unisba.

[6] Faridah. (n.d.). Pengaruh Efektivitas Model Pembelajaran Discovery Learning Terhadap Hasil Belajar Mata Pelajaran PAI Pada Siswa Kelas VIII Semester 1 SMP NU 01 Muallimin Weleri Tahun Pelajaran 2010-2011. 
[7] Ismail Sukardi, Indah Wigati, I. M. (2015). Pengaruh Model Pembelajaran Discovery Learning Terhadap Hasil Belajar Siswa Pada Mata Pelajaran PAI Kelas VII di SMP Patra Mandiri 01 Palembang. Fakultas Tarbiyah Dan Keguruan UIN Raden Fatah Palembang, Vol 1(No 1).

[8] Kholid Nugraha. (n.d.). Pengaruh Penggunaan Model Pembelajaran Discovery Learning Terhadap Hasil Belajar Siswa Pada Mata Pelajaran PAI (Kompetensi Dasar Mengenal Tata Cara Bersuci ) di Sekolah Dasar Islam Terpadu (SD IT) Al Hikmah Kota Cirebon.

[9] Lia Amaliah. (2019). Pengaruh Penerapan Model Pembelajaran Discovery Learning Pada Pelajaran PAI Terhadap Hasil Belajar Siswa di SMP Negeri 2 Kota Jambi.

[10] Nafidatun Nadhiroh. (2017). Pengaruh Model Discovery Learning Terhadap Hasil Belajar PAI Peserta Didik Kelas IV SD Islam Al-Azhar Tulungagung.

[11] Nafilatur Rahmah Qadarisman. (n.d.). Pengaruh Implementasi Model Discovery Learning Terhadap Hasil Belajar PAI Siswa Kelas X IIS-1 di SMA Al-Falah Surabaya.

[12] Nikamatul Rohmawati. (2020). Pengaruh Model Pembelajaran Discovery Learning Terhadap Hasil Belajar Siswa Pada Mata Pelajaran PAI Kelas XII Multimedia di Sekolah Menengah Kejuruan Negeri 1 Ponorogo Tahun Ajaran 2019/2020.

[13] Retnawati, H. (2018). Pengantar Analisis Meta. Parama Publishing.

[14] Roestiyah. (1998). Strategi Belajar Mengajar. Rhineka Cipta.

[15] Shilfia Alfitry. (2020). Pengaruh Penerapan Model Pembelajaran Discovery Learning Oleh Guru Terhadap Hasil Belajar Siswa Pada Mata Pelajaran Pendidikan Agama Islam di Sekolah Menengah Pertama Se-Kecamatan Rumbai Pesisir.

[16] Siti Umdlotul Khoiroh, Saat Ibnu Waqfin, H. R. (2020). Pengaruh Pendekatan Saintifik dengan Model Discovery Learning Terhadap Hasil Belajar Siswa pada Pelajaran PAI Kelas VII SMP A Wahid Hasyim Ngoro. Journal of Education and Management Studies, 3(3), 43-48.

[17] Subandi. (2016). Pengaruh Penerapan Model Pembelajaran Discovery Learning Terhadap Hasil Belajar Siswa dalam Mata Pelajaran Pendidikan Agama Islam (Studi di SMK Negeri 1 Kragilan).

[18] Suparno. (2001). Teori Perkembangan Kognitif Jean Piaget. Kanisius.

[19] Supriatna, D. (2018). Pengaruh Model Pembelajaran Discovery Learning Untuk Meningkatkan Hasil Belajar Pendidikan Agama dan Budi Pekerti Pada Siswa Kelas XIPA Di SMAN 5 Bekasi Pada Tahun 2017/2018. Research and Development Journal of Education, Vol 5(No 1).

[20] Tenti Anggreasi. (2017). Pengaruh Efektivitas Pembelajaran Pendidikan Agama Islam (PAI) Dengan Model Discovery Learning dalam Meningkatkan Hasil Belajar Siswa di SMP Negeri I Lawang Wetan.

[21] Tyas Rohmansyah. (2019). Pengaruh Penggunaan Model Discovery Learning Untuk Meningkatkan Akhlakul Karimah Pada Pelajaran Pendidikan Agama Islam Siswa Kelas X SMA Negeri 10 Bandar Lampung.

[22] Yasrida Yanti Sihombing. (2018). Pengaruh Penerapan Model Pembelajaran Discovery Learning dalam Upaya Peningkatan Hasil Belajar Siswa pada Pembelajaran PAI dan Budi Pekerti Pokok Bahasan Semua Bersih Hidup Jadi Nyaman di Kelas VII-1 SMP Negeri 1 Batangtoru Tahun Pelajaran 2018/2019. Vol 1(No 1). 